\section{Birlesik Dünya Arastrma Cypriot Journal of Educational \\ Sciences}

Volume 15, Issue 2, (2020) 232-245

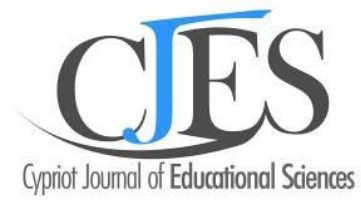

www.cjes.eu

\title{
High school students' higher education expectation: A scale development study
}

Yavuz Cetin, Faculty of Education, Education Programs and Teaching, Aydin Adnan Menderes University, 09100 Aydin, Turkey https://orcid.org/0000-0001-7257-1011

Beste Dincer*, Faculty of Education, Curriculum and Instruction, Aydin Adnan Menderes University, 09100 Aydin, Turkey https://orcid.org/0000-0002-9264-3665

\section{Suggested Citation:}

Cetin, Y. \& Dincer, B. (2020). High school students' higher education expectation: A scale development study. Cypriot Journal of Educational Science. 15(2), 232-245. https://doi.org/10.18844/cjes.v15i2.4617

Received September 2, 2019; revised February 5, 2020; accepted April 2, 2020.

${ }^{\circ} 2020$ United World Center of Research Innovation and Publication. All rights reserved.

\begin{abstract}
The aim of this study is to develop a valid and a reliable scale to determine the expectations of high school students from higher education. The population of the study consisted of 315 high school students in the 2018-2019 academic years. To test the construct validity of the scale, exploratory factor analysis and confirmatory factor analysis were used. The original five-point Likert scale composed of 22 items with five subdimensions. The results showed that the internal consistency coefficient of the scale was calculated as 0.84 . The scale factor load values ranged between 0.58 and 0.81 , and the rotated factor load values ranged between 0.46 and 0.81 and explained $59.1 \%$ of the total variance of the scale. The higher education expectation scale can be used not only to evaluate the students' future and professional expectations in terms of subjective norms but also goal setting and need for the analysis of the program development studies.
\end{abstract}

Keywords: High school students, expectation, scale development.

*ADDRESS FOR CORRESPONDENCE: Beste Dincer, Faculty of Education, Aydin Adnan Menderes University, 09100 Aydin, Turkey. E-mail address: bdincer@adu.edu.tr / Tel.: +90-256-218-2000 


\section{Introduction}

After the Second World War, the changing social and political framework, developing industry, the increase in scientific and technological activities brought out the demand for new employment profiles, and as a result, humane qualifications began to vary. The attention for higher education around the world has correspondingly increased, and since the 2000s, a period of growth and development in higher education has been observed in Turkey. As of November 2019, including 129 state institutions and 78 foundation institutions, there are a total of 207 higher education institutions in Turkey. In the 2018-2019 academic year, these institutions have 4,420,699 undergraduate, 2,829,430 associate, 394,174 graduate and 96,199 doctorate students registered in the Council of Higher Education (YOK) (Higher Education Information Management System, 2019).

The demand for higher education has reached a level increasing day by day. According to the data of 2019 Higher Education Institution Examination (YKS), the number of candidates applied to basic proficiency test (TYT) is 2,515,012, the number of candidates applied to the field proficiency test (AYT) is $2,024,549$ and the number of candidates applied to the foreign language test (YDT) is 13,775 (YKS Numeric Data, 2019).

Although there are many personal and social subreasons for individuals for higher education, the ultimate goal is to have a profession. It can be said that career choices are made in consideration of individual goals, economic prospects, role models or even by chance. The thought of social status and economic welfare are two significant motives when choosing a profession (Cakir, 2007). The occupational satisfaction and achievements are directly related to one's self-esteem and satisfaction with life; it has a great effect on the physical and mental well-being of an individual (Sevimli \& Iscan, 2005).

Failure in creating the appropriate professional placements can lead to a displeased social structure. Appropriate professional placements can only be performed by the right vocational guidance, carried out before the career choice. In this context, it is vital that high school students, who are to make a preference for higher education institutions, should consider the most appropriate professions for themselves and to have positive expectations for the future.

The concept of vocational guidance first appeared in the literature as career guidance and counseling in the 1970s (Herr \& Cramer, 1996). Even though there are many institutions and organisations in the vocational guidance field in Turkey (Turkey Employment Agency (ISKUR), universities, private sector and non-governmental organisations such as trade associations, the Ministry of National Education (MoNE) plays a crucial role in terms of compulsory education and accessibility. The workload and job definition of classroom counselor teachers and classroom psychological counselors at schools; psychological counselors working at Counseling and Research Center (RAM) (Akkok \& Watt, 2003). The greatest responsibility for this subject belongs to the counselor teachers at schools. In article 6 of the Psychological Counseling and Guidance Regulation, updated in 2017 by the MoNE and issued in the Official Gazette numbered 30,236, the definition of vocational guidance is as follows:

'Vocational Guidance: The service provided to the individual himself and his family in order to gain self-knowledge and knowledge of professions; making profession-oriented choices according to his abilities, interests, needs, values and personality characteristics; to get ready, start and maintain his profession and improve himself in the process of life-long learning.' (Official Paper, 2017).

Vocational guidance activities are carried out through promotions of universities, department visits and trips, promotional presentations and activities in Turkey. Thus, it is ensured that the students reach many goals such as the rise of the level of awareness about the occupations that they have an interest in setting goals and getting motivated to study.

In this field, some studies were conducted about high school students' career choices and factors affecting their choices with different samples and backgrounds. In the Zimbabwe sample, Mtemeri 
(2019) revealed that parents had an enormous effect on their children's career choices both directly and indirectly. It was also suggested in the study that parents should be involved in the children's career choices by the schools. Atli and Gur (2019) indicated that the most important determinant of students' choice of profession is the student himself. This was followed by parents, school teachers and school counsellors. Similarly, Berkant and Bahadir (2019) found out that almost all students thought that their personal characteristics, skills and interests would be the most effective in the selection of higher education programs. Then opportunities of employment and financial gain that the university provides for its students, universities' opportunities of scholarship, dormitory and overseas education, the image and reputation of higher education programs on the society and the academic staff of the university could be effective on the choice of higher education program.

In the conducted studies, it was obtained that higher education decisions are generally influenced by the internal factors (such as cognitive and emotional ability and interests) and external factors (such as socioeconomic condition, family and teachers). One has to make various choices throughout the life, but it can be said that one of the most crucial choices that affect adolescents' life is choosing a profession.

When considered from this point of view, the main objective of the study is to form a test tool to measure the psychometric factors that underlie the expectations of high school students about higher education. In this study, the exploratory factor analysis (EFA) and confirmatory factor analyses (CFA) were performed for the construct validity, and the validity and reliability analyses were performed considering the internal consistency coefficient (Cronbach Alpha) for the reliability of the 'high school students' higher education expectation' (HEES) developed by the researchers.

\section{Methodology}

The present study was designed to develop a valid and reliable scale to assess the high school students' expections from higher education. According to Karasar (2012), there are six phases of developing a scale concerning high school students' higher education expectations: creating the item pool, determining content validity, performing pre-application, collecting the data, examining the results of EFA and CFA and determining the reliability. These stages mentioned here were outlined as follows.

\subsection{Creating the item pool}

To create the scale items, 15 12th-grade students studying at a state Anatolian High School in the Aegean Region were questioned about their feelings, views and remarks of higher education and future expectations to them. The students were asked open-ended questions such as 'what are your expectations about higher education?', 'Which profession do you think you will be doing in the future?' and 'What are the factors that will affect your university preferences?' to report their thoughts in writing. The student views were analysed with a descriptive analysis technique, and a pool of 35 items was created by bringing similar items together. In addition, while the scale items were written, a literature review was conducted on higher education and future expectations (Kocyigit, Egmir \& Akcil, 2018; Ozyurek, 1995; Palti, 2012; Simsek, 2012; Tuncer, 2011), and the points to be considered while developing the scale were stated. Following this step, the item pool consisting of a total of 35 items was finalised based on students' views on higher education expectations.

\subsection{Determining content validity}

A preliminary examination was carried out by eight experts in their fields for scope validity studies. The items in the scale were given to two school counselors, four domain experts of education programs and teaching (one professor, one doctor lecturer and two doctoral students), one education management domain expert and one turkish language and literature teacher and asked to evaluate 
the draft structure. The experts were asked to examine the appropriateness of the draft according to the scale's content validity, comprehensibility, the representability of the targeted subject scope of the assessment instrument and the appearance validity criteria. In the draft form given to the experts, an answer form with the terms 'appropriate, needs to be corrected and, not appropriate' was used.

The experts found 18 items 8/8 appropriate, 6 items 7/8 appropriate and 6 items 6/8 appropriate. Besides, as a result of expert feedback, three items less than 4/8 fitness were removed from the draft scale. Following the expert feedback, a 32-item trial form was obtained. In parallel with the criticism and advice regarding the draft scale, the draft was finalised with 32 items. The final form came to a state that all items consist of positive statements and no reverse items.

\subsection{Pre-application}

At the pre-application stage of the scale, 22 students who were excluded from the study were randomly selected regardless of their demographic characteristics such as gender and academic achievement. At this stage, the students were observed to find out how long the study forms were filled out and how much the students understood the expressions on the form. It has been concluded that, at the pre-application stage, the duration of 12-15 minutes is sufficient to fill the scale.

\subsection{Collection of the data}

To perform the exploratory and CFA, the appropriate number is above the rate of five people per one statement. The trial form was applied to 315 students studying at an Anatolian high school in the Aegean region in the second semester of the 2018-2019 academic years, and the participants filled out the scale form in approximately 15 minutes on a volunteer basis. The demographic information of the students participating in the research is shown in Table 1.

Table 1. Demographic features of the sample

\begin{tabular}{lcccc}
\multicolumn{1}{c}{ Grade } & $\boldsymbol{f}$ & Gender & $\boldsymbol{f}$ & \% \\
\hline 9 & 69 & 21.9 & 60 & 19.1 \\
10 & 36 & 11.4 & 27 & 8.6 \\
11 & 48 & 15.2 & 30 & 9.5 \\
12 & 27 & 8.6 & 18 & 5.7 \\
Total & 180 & 57.1 & 135 & 42.9 \\
\hline
\end{tabular}

As shown in Table 1, 129 9th grade students (41\%), 63 10th grade students (20\%), 78 11th grade students $(24.8 \%)$ and 4512 th grade students (14.3\%) were participated in EFA. Of the research participants, 180 are female $(57.1 \%)$ and 135 are male $(42.9 \%)$ students.

The scale form, which was developed to be used in construct validity studies, was filled out in 10-15 minutes by research participants under the supervision of researchers in the 2 nd and 3rd weeks of April 2018-2019 academic year. The students were informed about the purpose of the research; the application instructions were read and all necessary explanations were made. Besides, the participants were warned to mark the option that suits best their subjective opinion and not to leave the items blank.

\subsection{Data analysis}

When the literature is reviewed, various opinions about the minimum sample size are found about the factor analysis applications. While some researchers state that the absolute sample size is important (Gorsuch, 1983; Kline, 1979; Tabachnick \& Fidell, 2007), another opinion suggests that the individual-variable number ratio is important (Bryant \& Yarnold, 1995; Cattell, 1978). In this context, it 
can be stated that the sample size should be at least 300 people or at least five times more than the number of items (Balci, 1995; Buyukozturk, 2011).

The sample size required for factor analysis was examined, and the study group was considered sufficient. With the data provided from 315 high school students, varimax rotation technique was applied in order to determine the construct validity of the scale for higher education expectations, and the EFA, which is used for finding factors, was conducted by using the principal component analysis and determining the relationship between the variables.

Afterwards, the CFA was used with the data obtained from the same sample group. Reliability values (Cronbach's alpha coefficient) were calculated for the entire scale and its subdimensions. The statistical analysis of the findings was carried out with SPSS 24.0 and LISREL 8.8 software programs.

\section{Findings}

The results of statistical analyses made to determine the validity and reliability levels of the HEES scale are shown in this section. Within the scope of validity studies, the EFA was performed for construct validity, CFA was performed for the confirmation of the obtained factor structure and finally reliability analysis was performed.

\subsection{Factor analysis (construct validity)}

The construct validity shows how accurately an assessment tool can measure an abstract fact or the degree of its ability to measure accurately (Buyukozturk, 2011; Tavsancil, 2010). In an effort to test the construct validity of the developed scale, these steps were carried out, respectively: (1) analysing the suitability of the data for factor analysis, (2) obtaining the factors, (3) rotating the factors, (4) naming the factors and (5) determining whether the variable groups contributing to the determined factor numbers are adequately represented by these factors.

The scale, which consists of 35 expressions, qualitatively preselected, was prepared in five-point Likert type. The distribution of points on the scale without negative statement items is 'I totally agree $=5$ points', 'I agree $=4$ points', 'I partially agree $=3$ points', 'I disagree $=2$ points' and 'I strongly disagree $=1$ point'.

Kaiser-Meyer Olkin (KMO) coefficient and Bartlett sphericity test were performed to test the suitability of the data for factor analysis. As (Buyukozturk, 2011) mentioned, if KMO is greater than 0.60 and has a value closer to 1 and the Bartlett test is significant, indicating that the data are suitable for factor analysis. Table 2 shows the values of KMO and Bartlett tests in our sample.

Table 2. Results of KMO and bartlett test

\begin{tabular}{ccc}
\hline KMO & $\mathbf{0 . 8 9}$ \\
\hline Bartlett sphericity test & Chi-square & $2,682.27$ \\
& df (Degree of & 231 \\
& Freedom) & \\
& $p$ & 0.000 \\
\hline
\end{tabular}

In the main component factor analysis, KMO value was found to be quite acceptable as 0.89 . This value shows that the data are appropriate for factor analysis (Tezer, Ozden \& Atasoy, 2019). The Bartlett sphericity test is a statistical method used to check whether the data come from a multivariate normal distribution. The significance of Chi-square $\left(X^{2}\right)$ test statistics is an indication that the data come from a multivariate normal distribution. Bartlett test performed in the study was found significant $\left(X^{2}=2,682.27 ; p<0.00\right)$. 
At this stage, anti-image correlation values of the items were also examined. Field (2005) stated that if the sample suitability measure for variables is less than 0.50 , the analysis should be repeated. Anti-image correlation values between the items are shown in Table 3.

Table 3. Anti-image correlation values between items

\begin{tabular}{lcccccccccccccccc}
\hline \multicolumn{1}{c}{ Item } & $\mathbf{1}$ & $\mathbf{2}$ & $\mathbf{3}$ & $\mathbf{4}$ & $\mathbf{5}$ & $\mathbf{6}$ & $\mathbf{7}$ & $\mathbf{8}$ & $\mathbf{9}$ & $\mathbf{1 0}$ & $\mathbf{1 1}$ & $\mathbf{1 2}$ & $\mathbf{1 3}$ & $\mathbf{1 4}$ & $\mathbf{1 5}$ & $\mathbf{1 6}$ \\
\hline $\begin{array}{l}\text { Anti-image } \\
\text { Coefficient }\end{array}$ & 0.84 & 0.59 & 0.59 & 0.91 & 0.88 & 0.91 & 0.83 & 0.88 & 0.90 & 0.92 & 0.92 & 0.94 & 0.69 & 0.94 & 0.87 & 0.86 \\
Item & 17 & 18 & 19 & 20 & 21 & 22 & 23 & 24 & 25 & 26 & 27 & 28 & 29 & 30 & 31 & 32 \\
$\begin{array}{l}\text { Anti-image } \\
\text { Coefficient }\end{array}$ & 0.91 & 0.85 & 0.93 & 0.94 & 0.64 & 0.83 & 0.80 & 0.86 & 0.89 & 0.68 & 0.70 & 0.61 & 0.93 & 0.91 & 0.71 & 0.88 \\
\hline
\end{tabular}

As shown in Table 3, the anti-image correlation coefficients of the items vary between 0.59 and 0.94. These results are recognised as critical evidences for the suitability of the data for factor analysis.

\subsubsection{Exploratory factor analysis}

The factor analysis study of the higher education expectation scale was conducted by applying the principle component analysis technique, which aims to reach variable reduction and meaningful conceptual structures. In order to support this study and to make the right decision on the number of factors, the Scree (line) graph, based on the eigenvalue of the factors, was examined. Varimax vertical rotation technique was used to gather items that show high correlation in one factor (Buyukozturk, 2011; Turgut \& Baykul, 1992; Ural \& Kilic, 2006).

At the end of the analysis of the main components made in the factor analysis stage and the rotating process with the Varimax technique, eight factors with an eigenvalue greater than 1.00 emerged. Due to these large number of factors, Cattel's Scree test was carried out. In Figure 1, the line graph (Scree test graph) of the factor eigenvalues is shown.

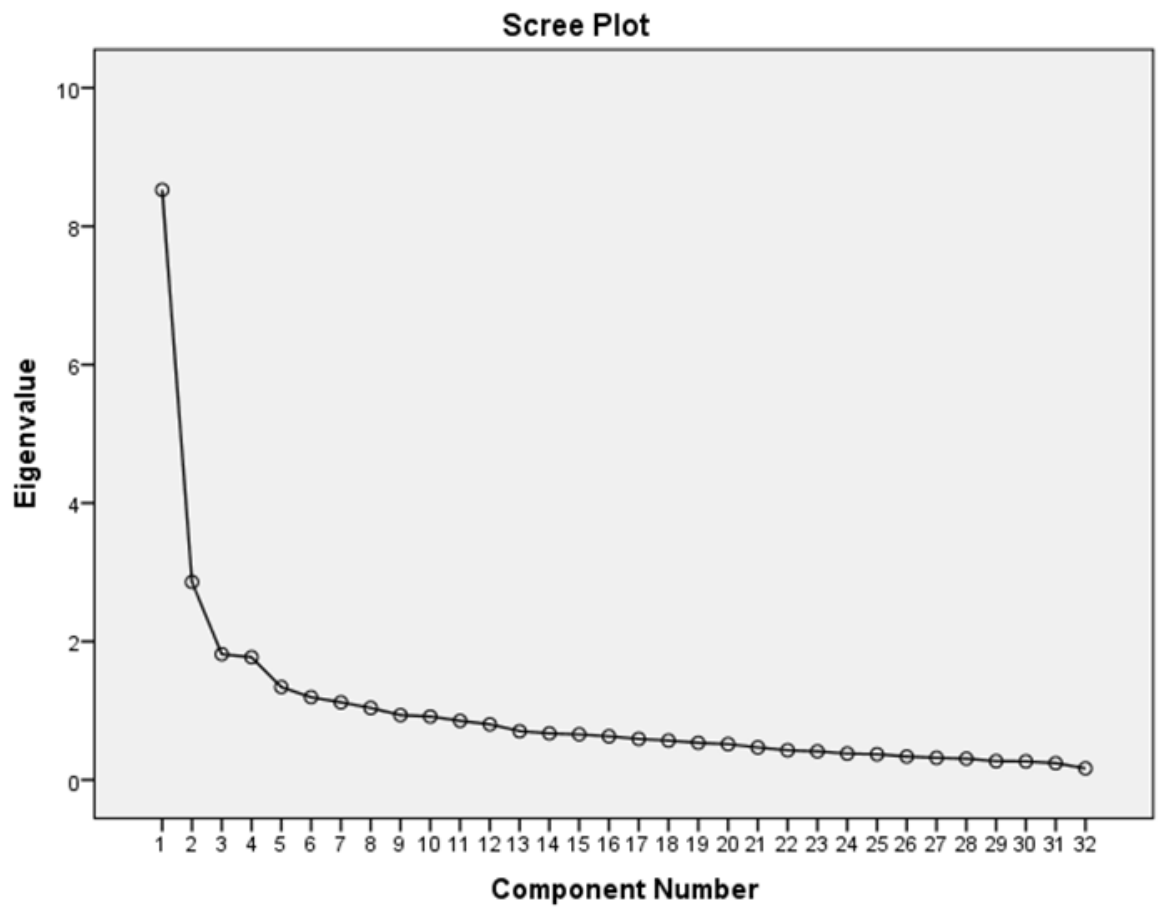

Figure 1. Scree plot of eigenvalues 
In the Scree plot, after the 5th item, the slope of the graph in Figure 1 was observed to be in the same direction, and the number of factors was adopted to be around this direction. After the Scree test, the next process is to extract the items from the scale.

The items 2, 3, 4, 13, 16, 17, 26, 27, 28 and 32 constituting one or two factors, which do not meet the condition that the items should have high load values in the factors (factor load minimum value is determined as 0.40 after the rotation process), having high load value in a single factor and low load value in other factors (at least 0.10 difference between high two load values), were excluded from the scale, according to the principle of high common factor variance explained by important factors in any item.

Accordingly, the five-factor 22-item higher education expectation scale was determined. The eigenvalues, their variance percentages and total variance percentages related to the items in these five factors are shown in Table 4.

Table 4. Variance explanation percentages of factors

\begin{tabular}{lccc}
\hline Factors & Eigenvalues & $\begin{array}{c}\text { Variance explanation } \\
\text { percentage (total) }\end{array}$ & $\begin{array}{c}\text { Variance explanation } \\
\text { percentage (cumulative) }\end{array}$ \\
\hline$F_{1}$ & 7.103 & 15.973 & 15.973 \\
$F_{2}$ & 2.088 & 13.093 & 29.066 \\
$F_{3}$ & 1.561 & 10.853 & 39.919 \\
$F_{4}$ & 1.173 & 9.718 & 49.637 \\
$F_{5}$ & 1.058 & 9.373 & 59.010 \\
\hline
\end{tabular}

As shown in Table 4, as a result of factor analysis, five factors with eigenvalues greater than 1 emerged. The variance explanation percentages of these factors are $15.973 \%, 13.093 \%, 10.853 \%$, $9.718 \%$ and $9.373 \%$, respectively. It is seen that the five factors obtained explain $59.01 \%$ of the total variance.

The factor loads of the items remained in the scale are shown in Table 5.

Table 5. Item factor load values and rotated factor load values

\begin{tabular}{|c|c|c|c|c|c|c|}
\hline \multirow[t]{2}{*}{ Item no } & \multirow{2}{*}{$\begin{array}{c}\text { Factor } \\
\text { load }\end{array}$} & \multicolumn{5}{|c|}{ Rotated factor load values } \\
\hline & & Factor 1 & Factor 2 & Factor 3 & Factor 4 & Factor 5 \\
\hline M1 & 0.578 & 0.726 & & & & \\
\hline M5 & 0.682 & 0.669 & & & & \\
\hline M14 & 0.611 & 0.644 & & & & \\
\hline M29 & 0.643 & 0.627 & & & & \\
\hline M12 & 0.645 & 0.599 & & & & \\
\hline M20 & 0.597 & 0.573 & & & & \\
\hline M19 & 0.558 & 0.529 & & & & \\
\hline M15 & 0.726 & & 0.820 & & & \\
\hline M7 & 0.573 & & 0.717 & & & \\
\hline M11 & 0.576 & & 0.675 & & & \\
\hline M30 & 0.542 & & 0.615 & & & \\
\hline M9 & 0.660 & & & 0.797 & & \\
\hline M10 & 0.636 & & & 0.669 & & \\
\hline M8 & 0.623 & & & 0.633 & & \\
\hline M6 & 0.576 & & & 0.626 & & \\
\hline M21 & 0.634 & & & & 0.771 & \\
\hline M22 & 0.553 & & & & 0.669 & \\
\hline M18 & 0.535 & & & & 0.635 & \\
\hline $\mathrm{M} 25$ & 0.368 & & & & 0.464 & \\
\hline
\end{tabular}




$\begin{array}{llllr}\text { M23 } & 0.611 & & & 0.741 \\ \text { M24 } & 0.640 & & & 0.706 \\ \text { M31 } & 0.414 & 7 & 4 & 4 \\ \text { Number of } & & & & 0.615 \\ \text { items } & & & & 3\end{array}$

The scale consists of 22 items collected under five factors. The first factor is thought to try to explain the future expectations of students arising from higher education. This factor is called 'Future Expectation'. The items under this factor range from 0.529 to 0.726 . The second factor is thought to try to explain the social expectations of students regarding their higher education life, and this factor is called 'gaining social respect'. Items under this factor range from 0.615 to 0.820 . The third factor is thought to try to explain the expectations of students about university education life. This factor is called 'training objectives'. Items under this factor range from 0.626 to 0.797 . The fourth factor is thought to be related to students' expectations that university life will try to change their personal life. This factor is called the 'socialising developing self-reliance'. Items under this factor range from 0.464 to 0.771 . The fifth factor is thought to try to explain the economic expectations of students about university life. This factor is called 'economic conditions'. Items under this factor range from 0.615 to 0.741 .

The relationship between the subdimensions of the higher education expectation scale (correlation between factors) was examined, and the results are shown in Table 6. It is suggested that the correlation coefficient between the subdimensions in terms of the multiple connection problem should not be 0.90 and above (Buyukozturk, 2011). The correlation values between the subdimensions of the scale are shown in Table 6.

Table 6. Correlation values between the subdimensions of the scale

\begin{tabular}{|c|c|c|c|c|c|}
\hline Subdimensions of the scale & $F_{1}$ & $F_{2}$ & $F_{3}$ & $F_{4}$ & $F_{5}$ \\
\hline Future expectation $\left(F_{1}\right)$ & 1 & $0.531^{*}$ & $0.595^{*}$ & $0.350^{*}$ & $-0.391^{*}$ \\
\hline Gaining social respect $\left(F_{2}\right)$ & & 1 & $0.504^{*}$ & $0.384 *$ & -0.104 \\
\hline Training objectives $\left(F_{3}\right)$ & & & 1 & $0.258^{*}$ & $-0.232^{*}$ \\
\hline $\begin{array}{l}\text { Demand for family distancing- } \\
\text { cultural enrichment }\left(F_{4}\right)\end{array}$ & & & & 1 & 0.005 \\
\hline Economic conditions $\left(F_{5}\right)$ & & & & & 1 \\
\hline
\end{tabular}

The correlation values between the subdimensions of the scale are shown in Table 6 . The data obtained show that there are meaningful relationships between the five dimensions of the scale, and there are no multiple connection problems. According to Buyukozturk, the relationship is low between 00.0 and 0.29 , medium between 0.30 and 0.69 and high between 0.70 and 1.00 . Based on this, it is confirmed that the highest relationship is between the first and third factors $(r=0.595 ; p<0.01)$, whereas the lowest relationship is between the second and fifth factors $(r=-0.104 ; p>0.05)$. These results show that the relationship between the subfactors of the assessment tool is at medium and low levels according to the classification made by Buyukozturk (2002).

\subsubsection{Confirmatory factor analysis}

CFA is the factor analysis used to test the fitness of the factors determined by EFA with the factor structures determined by the hypothesis. While EFA is used to test which variable groups are highly associated with which factor, CFA is used to determine whether variable groups contributing to the specified number are adequately represented by these factors (Aytac \& Ongen, 2012; Bayram, 2010).

The hidden factors in the structure of the scale and the interdependent effects between these factors were tested by creating a CFA model. Factors that have invisible variables of the higher 
education expectation scale, consisting of five dimensions, are interrelated and are shown in Figure 2 with two-way curved arrows.

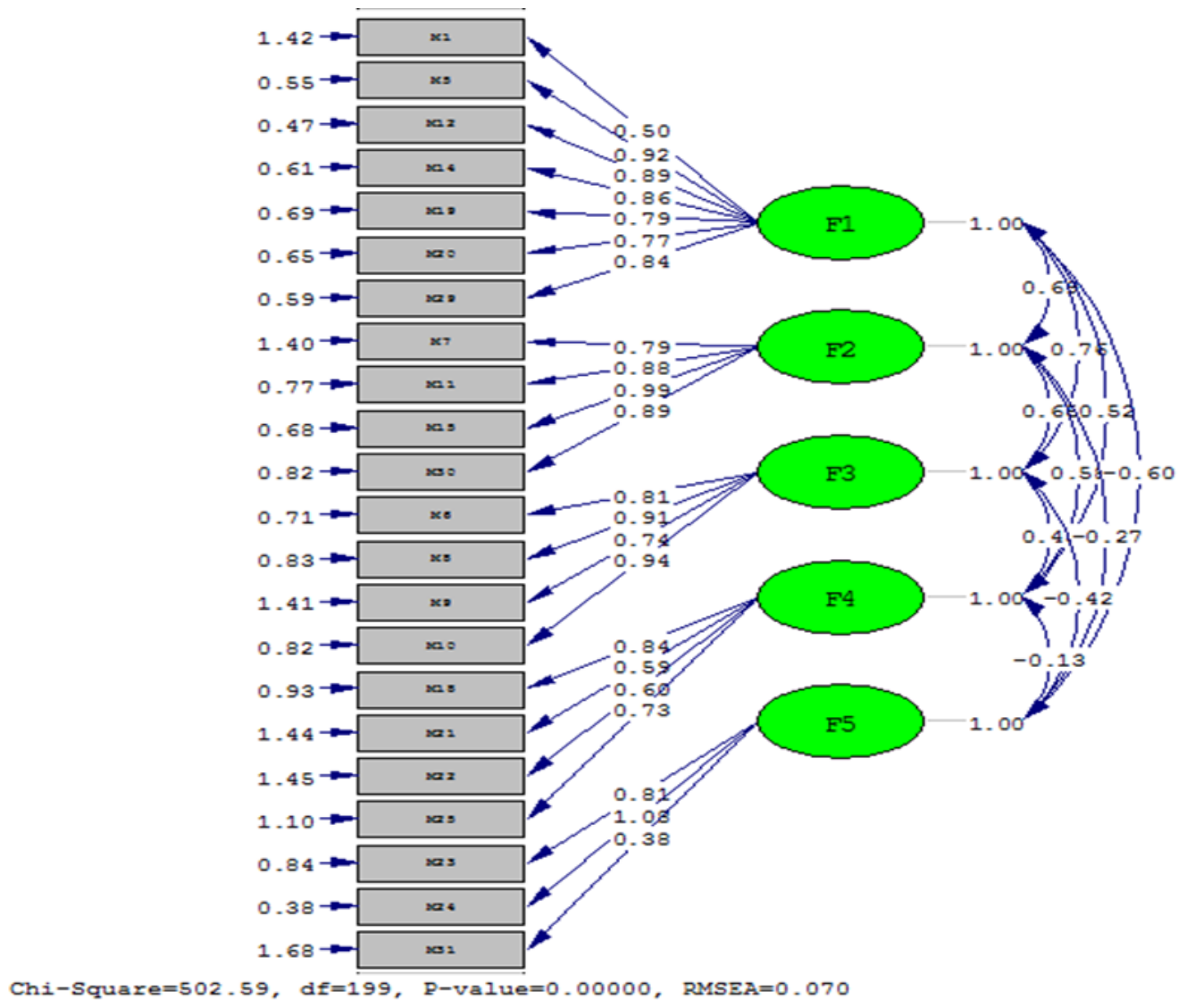

Figure 2. CFA path diagram of the scale

When Figure 2 is examined, it is seen that the higher education expectation scale, consisting of 22 items and five subfactors, is significant $\left(X^{2}=502.59, d f=199, p=0.00, X^{2} / d f=2.526\right)$. In large samples, the ratio of $X^{2} / d f$ below 3 corresponds to perfect fitness and below 5 corresponds to moderate fitness (Cokluk, Sekercioglu \& Buyukozturk, 2010). The standardised correlation values are statistically significant $(p<0.01)$, and the relationship between them is shown in Figure 2 .

It can be said that all the fit indices of this structural model created in the first level CFA analysis are at a good level. The comparison of the standard goodness of fit criteria with the results of the research is shown in Table 7.

Table 7. Results of CFA standard goodness of fit

\begin{tabular}{lcc}
\hline \multicolumn{1}{c}{ CFA compatibility values } & CFA analysis results & Acceptable cohesion criterion \\
\hline $\begin{array}{l}\text { Chi-Square }\left(X^{2}(2) / p \text { value }\right. \\
\text { Degree of freedom }(d f)\end{array}$ & $1902.59 / p=0.000(p<0.05)$ & \\
$\left(X^{2}(2) / d f\right.$ & 2.526 & $0-5$ \\
Root mean square error of & 0.07 & $0.00 \leq \mathrm{RMSEA} \leq 0.10$ \\
approximation (RMSEA) & & $0.80 \leq \mathrm{GFI} \leq 1.00$ \\
Goodness of fit index (GFI) & 0.87 & $0.85 \leq \mathrm{AGFI} \leq 1.00$
\end{tabular}
(AGFI) 


$\begin{array}{lcc}\text { Comparative fit index (CFI) } & 0.95 & 0.90 \leq \mathrm{CFI} \leq 1.00 \\ \text { NFI } & 0.93 & 0.90 \leq \mathrm{NFI} \leq 1.00 \\ \text { NNFI } & 0.95 & 90 \leq \mathrm{NNFI} \leq 1.00 \\ \text { Standardised root-mean-square } & 0.068 & 0.00 \leq \mathrm{SRMR} \leq 0.08 \\ \text { residual (SRMR) } & \end{array}$

Adapted from Schermelleh-Engel, Moosbrugger and Muller (2003).

Frequently used goodness of fit tests are GFI, AGFI, RMSEA, CFI, SRMR and root-mean-square residual (Harrington, 2009; Simsek, 2007). If RMSEA is equal to or less than 0.08 and $p$ value is less than 0.05, it shows that the fit is good (Harrington, 2009; Simsek, 2007), and if it is equal to or less than 0.10, it shows that the fit is weak (Harrington, 2009). According to Table 7, RMSEA is found as 0.0512. For a good model, the RMSEA value is preferred to be less than 0.08. If SRMR is less than 0.10 (Simsek, 2007), CFI value is equal to or above 0.90 (Harrington, 2009; Simsek, 2007), and AGFI is equal to or above 0.90, showing that there is a fit (Harrington, 2009). The goodness of fit index gives the values as follows: $\mathrm{GFI}=0.87, \mathrm{AGFI}=0.86, \mathrm{CFI}=0.95, \mathrm{NFI}=0.93, \mathrm{NNFI}=0.95$ and $\mathrm{SRMR}=0.068$. In this study, according to the values obtained in the final CFA with 22 items in the higher education expectation scale, it was determined that the fit is good.

\subsection{Findings related to the reliability of the scale}

According to Tavsancil (2002), it is recommended that the item test correlations are 0.30 and above for the items in the scale. At this stage, the studies were carried out to determine the internal consistency of the scale. Cronbach's alpha coefficient was calculated for each dimension of the higher education expectation scale and for the overall scale.

Table 8. Reliability coefficient of the general avarage score of the scale and reliability coefficients for each subdimension

\begin{tabular}{|c|c|c|}
\hline Factor & Number of items & Cronbach's alpha $(\alpha)$ \\
\hline $\mathrm{F}_{1}$ & 7 & 0.86 \\
\hline $\mathrm{F}_{2}$ & 4 & 0.77 \\
\hline $\mathrm{F}_{3}$ & 4 & 0.76 \\
\hline $\mathrm{F}_{4}$ & 4 & 0.62 \\
\hline $\mathrm{F}_{5}$ & 3 & 0.61 \\
\hline Scale & 22 & 0.84 \\
\hline
\end{tabular}

Cronbach's alpha $(\alpha)$ coefficient is accepted as a measure of the consistency of the scores of the components with the combined test scores (Baykul, 2000). The $\alpha$ coefficient is an indicator of the consistency of the subitems related to the properties of a scale with the feature to be measured. According to Table 8, Cronbach's alpha coefficient of the scale was calculated as 0.84 . As the calculated value is higher than 0.70 , it can be referred that the reliability is high for the entire scale (Tezbasaran, 2008). Considering the internal reliability coefficients of the factors, the first factor is $\alpha=0.86$, the second factor is $\alpha=0.77$, the third factor is $\alpha=0.76$, the fourth factor is $\alpha=0.62$ and the fifth factor is $\alpha=0.61$.

The total score averages of 315 people, who constitute the study group in order to determine the item distinctiveness characteristics of 22 items that make up the scale and 5 factors that they are dimensioned, are ranked in an ascending order and the total score averages of 85 people, $27 \%$ of the lower and upper groups in the study group, were compared with the $t$-test for the entire scale, dimensions and each item. The $t$-test results are shown in Table 9 for the dimensions and the entire scale. 
Table 9. The $t$-test results based on the lower-upper group averages for dimensions and scale

\begin{tabular}{|c|c|c|c|c|}
\hline Factor & Group & Arithmetic average & Standard deviation & $t$-test \\
\hline \multirow[t]{2}{*}{$F_{1}$} & Lower group & 17.98 & 5.34 & $39 *$ \\
\hline & Upper group & 29.13 & 0.75 & \\
\hline \multirow[t]{2}{*}{$F_{2}$} & Lower group & 9.32 & 2.38 & $38.96 *$ \\
\hline & Upper group & 19.20 & 0.80 & \\
\hline \multirow[t]{2}{*}{$F_{3}$} & Lower group & 9.59 & 2.38 & $38.81 *$ \\
\hline & Upper group & 19.20 & 0.83 & \\
\hline \multirow[t]{2}{*}{$F_{4}$} & Lower group & 8.09 & 1.87 & $39 *$ \\
\hline & Upper group & 16.89 & 1.43 & \\
\hline \multirow[t]{2}{*}{$F_{5}$} & Lower group & 3.89 & 0.85 & $39 *$ \\
\hline & Upper group & 10.87 & 1.80 & \\
\hline
\end{tabular}

As shown in Table 9, it is clear that there is a significant difference at the $p<0.01$ level between the total score averages between the upper and lower groups in the entire scale and between the dimensions. It was determined that this difference is in favor of the students in the upper group. This result is accepted as a proof for the construct validity of the scores obtained with the assessment tool, according to the opposite group method.

\section{Conclusion and suggestions}

While psychomotor skills are mostly determined by observations, the tools most commonly used in assessing cognitive and affective characteristics are the scales known as psychological tests. All the tools used in assessing psychological features are in a dynamic form, and it is expected that each research that is done with these tools will contribute to the further clarification of psychometric features (Bozanoglu, 2004).

The originally developed scale has 22 items. To assess the item quality, expert feedbacks (two teachers from the guidance and psychological counseling branch and five experts in the field of educational sciences) were received. Moreover, determine whether the items are understandable in terms of language and grammar, a language specialist was asked to provide feedback, and the items were finalised.

The validity and reliability studies were conducted to determine the psychometric properties of the scale. In the validity studies, EFA was performed to reveal the factor structure of the scale, and CFA was performed to determine the accuracy of this structure. As a result of the EFA, the items with a factor load below 0.45 were removed from the scale. Furthermore, the items which load two factors and where the difference between the load values of the items is 0.10 and below were removed. After the elimination of the mentioned items, as a result of the repeated explanatory factor analysis, an assessment instrument explaining $59.1 \%$ of the total variance, consisting of 22 items, with a fivedimensional structure, was obtained including 'future expectation' (items 1, 5, 12, 14, 19, 20 and 29), 'gaining social respect' (items 7, 11, 15 and 30), 'training objectives' (items 6, 8, 9 and 10), 'socialising developing self-reliance' (items 18, 21, 22 and 25) and 'economic conditions' (items 23, 24 and 31).

The score that can be gained from the five-point Likert scale varies between 22 and 110 . The low scores indicate that the student's expectation about higher education is low, whereas the high scores indicate that the student's expectation about higher education is high.

The model fit of the five-factor structure obtained by EFA was tested by CFA. As a result of the CFA, the model fit index $\left(X^{2}=502.59, d f=199, p=0.000, X^{2} / s d=2.526\right)$ of the scale, consisting of 22 items and five factors, was significant, and the fit indexes (RMSEA $=0.07, \mathrm{SRMR}=0.068, \mathrm{NNFI}=0.95, \mathrm{NFI}=$ $0.93, \mathrm{CFI}=0.95, \mathrm{GFI}=0.87$ and $\mathrm{AGFI}=0.85$ ) were found at a good level. Thus, according to the CFA 
results, the scale's model fit indexes are sufficient, and the scale which has construct validity was obtained.

As a result of the item analysis carried out for the whole scale, its dimensions and items, a significant difference between the total scores of the lower and upper groups was observed. Accordingly, it can be said that the distinctiveness levels of the scale, its subdimensions and items are high. In order to determine the reliability of HEES, internal consistency test method was conducted. As a result of the analyses, it is seen that the reliability coefficient obtained by the internal consistency method is 0.84 for the scale and $0.86,0.77,0.76,0.62$ and 0.61 for the subdimensions of the scale, respectively. As a result, it can be stated that the reliability of the assessment tool is high, when the 0.70 coefficient (Tabachnick \& Fidell, 2007) is taken as a criterion for the Cronbach's alpha coefficient obtained by the internal consistency method.

The scale called HEES in short developed within the scope of this study aims to reveal the cognitive and affective characteristics of students related to higher education. As a result of the validity and reliability analyses conducted within the framework of this study, it can be said that HEES namely is a valuable assessment tool that will contribute much to the relevant field.

Based on these findings, suggestions that are thought to guide future research works are presented as follows:

The higher education expectation scale was developed for high school students, and it was aimed to evaluate students' future and professional expectations in terms of subjective norms. Taking into consideration that the changing world conditions significantly affected the choice of professions of students, it is also recommended to research the longditional studies carried out at the national level to enable the generalisation of the findings.

Enrolling in higher education may not always be seen a guarantee of good employment. Apart from evaluating special career development and career choices of the students, this scale may help students to be aware of their own decision about continuing their education at a university level or not. In this context, it can be used in high schools as vocational guidance and counseling practices offered within the scope of vocational guidance services, psychological counseling as for student recognition, goal setting and need for the analysis for curriculum development.

\section{References}

Akkok, F. \& Watts, A. G. (2003). Public policies and career development: A framework for the design of career information, guidance and counseling services in developing and transition countries. Ankara, Turkey: World Bank.

Atli, A. \& Gur, S. H. (2019). High schools students career choices and factors affecting their choices. Turkish Pyschological Counselling and Guidance Association, 2(1), 32-53.

Aytac, M. \& Ongen, B. (2012). Dogrulayici faktor analizi ile yeni cevresel paradigma olceginin yapi gecerliliginin incelenmesi. [Investigation of the structure validity of the new environmental paradigm scale with CFA]. Istatistikciler Dergisi, 5, 14-22.

Balci. A. (1995). Sosyal bilimlerde arastırma, yontem, teknik ve ilkeler [Research, methods, techniques and principles in social sciences]. Ankara, Turkey: Pegem-A Yayincilik.

Baykul, Y. (2000). Egitimde ve psikolojide olcme [Measurement in education and psychology]. Ankara, Turkey: OSYM Yayinlari.

Bayram, N. (2010). Yapisal esitlik modellemesine giris [introduction to structural equation modeling]. Bursa, Turkey: Ekin Kitabevi.

Berkant, H. G. \& Bahadır, S. (2019). Factors affecting twelfth grade students' higher education choices and their preferences for teacher education programs. OPUS-International Journal of Society Reseraches, 11(18), 1897-1940. doi:10.26466/opus.567578. 
Bozanoglu, I. (2004). Akademik gudulenme olcegi: Gelistirmesi, geçerligi, guvenirligi [Academic Motivational Scale: Development, validity and reliability]. Ankara Universitesi Egitim Bilimleri Fakultesi Dergisi, 37(2), 83-98. doi:10.1501/Egifak_0000000094.

Bryant, F. B. \& Yarnold, P. R. (Eds.). (1995). Principal-components analysis and exploratory and confirmatory factor analysis. Washington, DC: American Psychological Association.

Buyukozturk, S. (2002). Faktor analizi: Temel kavramlar ve olcek gelistirmede kullanimi [Factor analysis: Main concepts and usage in scale development]. Kuram ve Uygulamada Egitim Yonetimi, 32, 470-483.

Buyukozturk, S. (2011). Sosyal bilimler icin veri analizi el kitabi [Data analysis manual for social sciences] (14. Baski). Ankara, Turkey: Pegem-A Yayincilik.

Cakir, M. A. (2007). Mesleki rehberlik [Vocational guidance] (Ed: Alim Kaya). Ankara, Turkey: Ani Yayincilik.

Cattell, R. B. (1978). The Scientific use of factor analysis. New York, NY: Plenum.

Cokluk, O., Sekercioglu, G., \& Buyukozturk, S. (2010). Sosyal bilimler için cok degiskenli istatistik: SPSS ve Lisrel uygulamali [Multivariate statistics for social sciences: SPSS and Lisrel applied]. Ankara, Turkey: Pegem Yayincilik.

Field, A. (2005). Discovering statistics using SPSS. London, UK: SAGE Publishing.

Gorsuch, R. L. (1983). Factor analysis. Hillsdale, NJ: Erlbaum.

Harrington, D. (2009). Confirmatory factor analysis. New York, NY: Oxford University Press.

Herr, E. L. \& Crammer, S. H. (1996). Career guidance and counseling through the lifespan (5th ed.). New York, NY: Harper Collins Publishers.

Higher Education Information Management System. (2019). Retrieved from https://istatistik.yok.gov.tr/.

Karasar, N. (2012). Bilimsel arastirma yontemi: Kavramlar, ilkeler, teknikler [Scientific research method: Concepts, principles, techniques ] (23. Basim). Ankara, Turkey: Nobel Yayinlari.

Kline, P. (1979). Psychometrics and psychology. London, UK: Acaderric Press.

Kocyigit, M., Egmir, E. \& Akcil, M. (2018). A glance at education and higher education from the perspective of high school senior students. MANAS Journal of Social Studies, 7(3), 119-141.

Mtemeri, J. (2019). Family influence on career trajectories among high school students in midlands province, Zimbabwe. Global Journal of Guidance and Counseling in Schools: Current Perspectives, 9(1), 24-35. doi:10.18844/gjgc.v9i1.4229.

Official Paper. (2017). Retrieved from https://www.resmigazete.gov.tr/eskiler/2017/11/20171110-2.htm

Ozyurek, R. (1995). Kiz ve erkek on birinci sinif ogrencilerinin kariyer yetkinlik beklentisi, kariyer secenekleri zenginligi, akademik performans ve yetenekleri arasındaki iliski [The relationship between the male and female eleventh grade students' career competence expectation, wealth of career options, academic performance and abilities ]. Turk Psikolojik Danisma ve Rehberlik Dergisi, 2(7), 19-32.

Palti, C. (2012). Universiteye hazirlanan lise son sinif ogrencilerinde yuksekogretime gecis sinavi oncesi ve sonrasinda benlik saygisi, sinav kaygisi ve durumlu-surekli kaygi duzeyleri. [Self-esteem before and after the transition to higher education in high school final year students preparing for university, exam anxiety and state-trait anxiety levels]. (Unpublished master thesis). Istanbul Universitesi Sosyal Bilimler Enstitusu, Istanbul, Turkey.

Schermelleh-Engel, K., Moosbrugger, H. \& Muller, H. (2003). Evaluating the fit of structural equation models: Tests of significance and descriptive goodness-of-fit measures. Methods of Psychological Research Online, $8(2), 23-74$.

Sevimli, F. \& Iscan, O. F. (2005). Bireysel ve is ortamina ait etkenler acisindan is doyumu [Job satisfaction in terms of individual and work environment factors]. Ege Akademik Bakis Dergisi, 5(1), 55-64.

Simsek, H. (2012). Guneydogu Anadolu bolgesindeki lise ogrencilerinin gelecek beklentileri ve gelecek beklentilerini etkileyen faktorler [The future expectations and the factors that effect future expectations of high school students in the Southeastern Anatolia region]. Kuramsal Egitimbilim Dergisi, 5(1), 90-109.

Simsek, O. F. (2007). Yapisal esitlik modellemesine giris: Temel ilkeler ve LISREL uygulamalari [Introduction to structural equation modeling: Basic Principles and LISREL Applications]. Ankara, Turkey: Cem Web Ofset.

Tabachnick, B. G. \& Fidell, L. S. (2007). Using multivariate statistics. (5th ed.). London, UK: Pearson Education, Inc.; Boston, MA: Allyn and Bacon. 
Tavsancil, E. (2010). Tutumlarin olculmesi ve SPSS ile veri analizi [Measurement of attitudes and data analysis with SPSS] (4th ed.). Ankara, Turkey: Nobel Yayin Dagitim.

Tezbasaran, A. (2008). Likert tipi olcek hazirlama kilavuzu [likert type scale preparation guide]. Mersin, Turkey: Turk Psikologlar Dernegi.

Tezer, M., Ozden, C. \& Atasoy, R. (2019). Developing a technology and design course self-efficacy scale: A validity and reability study. World Journal on Educational Technology: Current Issues, 11(3), 186-197. doi:10.18844/wjet.v11i3.4247

Tuncer, M. (2011). Yuksekogretim gencliginin gelecek beklentileri uzerine bir arastirma [A study on future prospects of higher education youth]. Turkish Studies, 6(2), 935-948. doi:10.7827/Turkish Studies.2265

Turgut, M. F. \& Baykul, Y. (1992). Olcekleme teknikleri [Scale techniques]. Ankara, Turkey: OSYM Yayinlari.

Ural, A. \& Kilic, I. (2006). Bilimsel arastirma sureci ve SPSS ile veri analizi [Scientific research process and data analysis with SPSS]. Ankara, Turkey: Detay Yayincilik.

YKS Numeric Data. (2019). Retrieved from https://dokuman.osym.gov.tr/pdfdokuman/2019/YKS/sayisalbilgiler18072019.pdf $\quad$ Ankara: OSYM Publications 